\title{
KEPEMIMPINAN KIAI DALAM PENGEMBANGAN PENDIDIKAN FORMAL DI PONDOK PESANTREN FULL DAY SUNAN AMPEL BANYUWANGI
}

\author{
Ahmad Aziz Fanani \\ IAI Ibrahimy Genteng Banyuwangi \\ Email: fananiahmadaziz89@gmail.com
}

\begin{abstract}
The focus in this study are: 1) how the behavior of the Kiai recognizes the situation of the pesantren community, 2) the behavior of the Kiai in providing direction and guidance to the community of the pesantren, 3) the behavior of the Kiai giving the delegation of authority to the pesantren community in developing formal education. Type of phenomenological research. Data collection techniques using observation, interviews, documents, and audiovisual materials. Data analysis tools used interactive models. The results of this study: 1) the process of diagonalizing the Kiai which is carried out in the internal and external environment of the pesantren applies three important components, namely religious compatibility, commitment, and competence, 2) direction and guidance of the Kiai is carried out based on the maturity of the community which is described rationally through Kiai's scatted concept of maturity rate, 3) variable delegation of authority based on the scale of maturity and the development of a hierarchical structure. The conditions develop according to the competency scale, while the initiation is in line with the development of commitment.
\end{abstract}

\section{Keywords: Situational Leadership, Formal Education and Islamic Boarding} Schools

\begin{abstract}
Abstrak
Fokus dalam penelitian ini yaitu: 1) bagaimana perilaku Kiai mengenal situasi civitas pesantren, 2) perilaku Kiai memberikan pengarahan dan bimbingan kepada civitas pesantren, 3) perilaku Kiai memberikan pelimpahan wewenang kepada civitas pesantren dalam pengembangan pendidikan formal. Jenis penelitian fenomenologi. Teknik pengumpulan data menggunakan observasi, wawancara, dokumen dan bahan audiovisual. Alat analisis data yang di gunakan Interaktif model. Hasil dari penelitian ini: 1) proses diagonasa Kiai yang dilakukan pada lingkungan internal maupun external pesantren menerapkan tiga komponen penting yakni kompatibilitas agama, komitmen dan kompetensi, 2) arahan dan bimbingan Kiai dilakukan berdasarkan kematangan civitasnya yang digambarkan secara rasional melalui Kiai's scatted concept of maturity rate, 3) pendelagasian wewenang berubah-ubah berdasarkan skala kematangan dan perkembagan hirarki struktur. Kosedarasi berkembang sesuai dengan skala komptensi, sedangkan inisiasi searah dengan perkembangan komitmen.
\end{abstract}

Kata Kunci: Kepemimpinan Situasional, Pendidikan Formal dan Pesantren 


\section{A. Pendahuluan}

Menurut Halim (2005:44) memasuki abad ke-21, berbagai perkembangan dan perubahan terjadi akibat globalisasi dunia yang sangat cepat dalam semua aspek kehidupan manusia. Sifat individualis dan pola hidup materialistik yang kian mengental merupakan fenomena globalisasi. Disinilah keunikan pondok pesantren yang masih konsisten dengan menyuguhkan suatu sistem pendidikan yang mampu menjembatani kebutuhan fisik (jasmani) dan kebutuhan mental spiritual (rohani) manusia. Mulyasa (2004: 3) bahwa visi pembangunan di era reformasi diarahkan pada terwujudnya masyarakat Indonesia yang damai, demokratis, berkeadilan, berdaya saing, maju dan sejahtera dalam wadah Negara Kesatuan Republik Indonesia yang didukung oleh manusia Indonesia yang sehat, mandiri, beriman, bertaqwa, berakhlak mulia, cinta tanah air, berkesadaran hukum, dan lingkungan,menguasai ilmu pengetahuan dan teknologi, memiliki etos kerja yang tinggi serta berdisiplin.

Perwujudan manusia yang berkualitas tersebut menjadi tanggung jawab pendidikan, terutama dalam mempersiapkan peserta didik menjadi subyek yang makin berperan menampilkan keunggulan dirinya yang tangguh, mandiri, kreatif dan profesional pada bidangnya masing-masing. Hal tersebut diperlukan, terutama untuk mengantisipasi dan menghadapi era kesejagatan, khususnya globalisasi pasar bebas di lingkungan Negara-negara ASEAN, seperti AFTA (Asean Free Trade Area), dan AFLA (Asean Labour Area), maupun di kawasan Negara-negara Asia Pasifik (APEC).Selanjutnya pada akhir 2015, Indonesia memberlakukan MEA (masyarakat ekonomi ASEAN) (Jawa Pos:2015)

Perihal diatas memberikan semangat kepada pesantren untuk selalu eksis dan melakukan perbaikan, pengembangan dan bahkan perubahan organisasi, baik dari segi sumberdaya manusia terutama dari sisi kepemimpinan Kiai, sumberdaya meterial maupun sumberdaya yang liannya serta memberikan layanan yang lebih baik dengan menyesuaikan arus perubahan zaman. Apalagi hari ini telah diterbitkan aturan UU nomor 18 tahun 2019 tentang Pesantren. Aturan yang resmi pada tahun 2019 kemarin, tentu merupakan dasar kuat agar pesantren secara mandiri dapat mengembangkan organisasi pendidikan sesuai dengan kebutuhan zaman. 
Penelitian dilakukan untuk mengkaji pesantren dari sudut pandang kepemimpinannya, yang secara entitas etnografis, dinyatakan sebagai seorang Kiai. Dari pengamatan Al Gini (2013:17) menyatakan jika paradigma yang dibangun untuk mengkaji hal tersebut memanglah cukup beragam, mulai dari membaca kepemimpinan Kiai dari sudut pandang otokratik, demokratik, dan tipologi kepemimpinan baru yang didasarkan pada sumber postulat personal. Amrullah (2011) ada juga yang memberikan atribusi kepemimpinan Kiai dari sudut pandang ke-khas-an dan karekteristik personal, misalnya; kepemimpinan Kiai politik dalam pengembangan lembaga pendidikan pesantren, kepemimpinan Kiai entrepreneur dalam membangun lembaga, dan Kiai pesantren (baca; muqim) dan mengandalkan sisi-sisi kekuatan sumberdaya manusia di dalamnya. Shodiq (2011) mengemukakan kepemimpinan Kiai dilihat dari sudut pandang geneologis; ada kepemimpinan Kiai nasab (keturanan) atau Kiai nasib (mendirikan sendiri pondok pesantren).

Para Kiai selalu dipersepsikan sebagai simbol keagamaan yang bisa merusak sekaligus memperbaiki (cultural brooker) budaya tersebut. Mardiyah (2012) menyatakan bahwa kepemimpinan Kiai yang berhubungan dengan situasi dan kondisi masyarakat, serta memiliki pengaruh didalamnya, tidak bisa dilepaskan dari peranan para Kiai itu sendiri. Adapun alasan Hasan (1987: 76) terkait posisi dan situasi kepemimpinan Kiai di aman pondok pesantren ialah; pertama, dimensi kemasyarakatan; Kiai merupakan representasi kebudayaan sekaligus situasi sosial yang berkelindan di dalam masyarkat. Kedua, pemimpin intelektual (ulama'), yakni; seseorang yang memiliki otoritas keilmuan di bidang keilmuan dan keberagamaan. Ketiga, pemimpin kerohanian atau spiritual (inner aspects of human lifes). Keempat, pemimpin administratif, yakni Kiai berperan sebagai sosok yang memiliki kemampuan untuk mengatur dan mengelola lembaga yang didirikannya. Dengan beragamnya dimensi yang melekat pada pribadi Kiai, maka keberadaan seorang Kiai sebagai pemimpin pondok pesantren, ditinjau dari tugas dan fungsinya dapat dipandang sebagai fenomena kepemimpinan yang unik.

Berangkat dari perihal diatas maka penulis mengkaji dan mendeskripsikan tentang perilaku Kiaidalam mengenal situasi, perilaku Kiai dalam memberikan pengarahandan bimbingan dan perilaku Kiai dalam memberikan pelimpahan 
wewenang kepada civitas pesantren dalam proses pengembangan pendidikan formal. Sehingga penelitian ini akan bermanfaat bagi pesantren secara umum untuk dijadikan sebagai bahan informasi bagi penyelenggaraan dan pengembangan pendidikan formal dari sisi kepemimpinan situasional Kiai.

\section{B. Landasan Teori}

Pada konteks memahami pemebahasan ruang lingkupnya ini, tentu diangap perlu untuk memahami lebih dahulu teori ruang lingkup kajin dasar kepemimpinan. Kepemimpinan dalam suatu organisasi memiliki peran yang sangat penting. Seorang pemimpin selain mampu merumuskan visi, misi, tujuan dan strategi pencapaian juga bertugas memimpin, mengarahkan, memotivasi kelompok untuk mencapai tujuan yang ditentukan. Menurut Robbins (2015:249) mengatakan bahwa kepemimpinan adalah kemampuan untuk mempengaruhi suatu kelompok menuju pencapaian sebuah visi atau tujuan yang telah ditetapkan. Menurut Mc Shane (2008:56) kepemimpinan adalah suatu proses mempengaruhi orang lain dan menyediakan ruang/lingkungan bagi mereka untuk mencapai tujuan organisasi atau kelompok.

Gibson (2007:32) lebih menekankan pada upaya menggunakan berbagai jenis pengaruh yang bukan paksaan untuk memotivasi anggota organisasi untuk mencapai tujuan tertentu dalam hal ini konteks kepemimpinan yang dikemukakan juga kelompok atau organisasi tapi menambahkan unsur motivasi yang memperjelas bahwa upaya yang dilakukan pemimpin bukan bersifat memaksa. Sedangkan Certo (2009:103) mengemukakan kepemimpinan dalam konteks yang lebih luas yakni bahwa kepemimpinan adalah proses mengarahkan perilaku orang lain untuk mencapai beberapa tujuan.

Berdasarkan beberapa pendapat ahli diatas pada dasarnya adalah sama, yakni menyangkut unsur proses terkait mempengaruhi, mengarahkan dan memberikan semangat) yang mengarah pada suatu tujuan yang akan dicapai. Dengan demikian kepemimpinan adalah proses di mana seseorang mempengaruhi, mengarahkan, memotivasi dan membuat orang lain bekerja sama serta memberikan kontribusinya pada pencapaian tujuan organisasi.

Robbins (2015:49) menyatakan teori sifat memusatkan perhatian pada diri para pemimpin itu sendiri, oleh karena itu teori ini lebih dikenal sebagai teori 
pembawaan .Beberapa pakar perilaku organisasi telah mengemukakan beberapa sifat yang dimiliki individu yang bisa membuatnya menjadi seorang pemimpin diantaranya McShane (2008:58) menyebutkan beberapa sifat khusus yang membuat seseorang menjadi pemimpin adalah drive, motivasi memimpin, integritas, kepercayaan diri, kecerdasan, pengetahuan bisnis dan kecerdasan emosional.Sifat-sifat khusus tersebut dikemukakan pula oleh Robbins (2015: 251) yang berbeda hanya karena dimasukkannya unsur ekstraversion.

Penelitian tentang teori sifat ini banyak dilakukan oleh peneliti Ohio State University. Dari bebeapa penelitianya mengindikasikan bahwa sifat pimpinan didasarkan pada dua dimensi yaitu consideration dan initiating structure. Keramahan (consideration) adalah sampai sejauh mana hubungan pekerjaan seseorang dicirikan oleh rasa saling percaya, menghormati gagasan dari para pekerja, dan menghargai pekerjaan mereka.

Seorang pemimpin dengan consideration yang tinggi sangat mempertimbangkan rasa kemanusiaanya. Pemimpin seperti ini biasanya sensitif akan perasaan orang-orang disekitarnya, dan selalu mencoba untuk melakukan hal terbaik bagi bawahannya, mendengarkan keluhan dan pendapat bawahan, memperlakukan bawahan secara adil, dan menunjukkan perhatian pada kebutuhan bawahan. Memprakarsai stuktur (initiating structure) adalah sampai sejauhmana seorang pemimpin akan mendefinisikan serta menstrukturisasi peranan dan para pekerjaannya dalam mencapai tujuan.

Teori perilaku menurut pendekatan perilaku, pendekatan sifat tidak dapat menjelaskan apa yang menyebabkan kepemimpinan itu efektif. Oleh karenanya, pendekatan perilaku tidak lagi berdasarkan pada sifat seorang pemimpin melainkan mencoba menentukan apa yang dilakukan oleh pemimpin efektif, seperti bagaimana mereka mendelegasikan tugas, bagaimana mereka berkomunikasi dan memotivasi bawahan, bagaimana mereka menjalankan tugastugas dan sebagainya. Aspek perilaku kepemimpinan menekankan fungsi-fungsi yang dilakukan pemimpin dalam kelompoknya. Agar kelompok berjalan efektif, seseorang harus melaksanakan dua fungsi utama, yaitu (1) fungsi-fungsi yang berhubungan dengan tugas (task-related) atau pemecahan masalah, dan (2) fungsifungsi pemeliharaan kelompok (Group-maintenance) atau sosial. 
Teori perilaku penelitian banyak dilakukan oleh peniliti dari Michigan University study. Berdasarkan beberapa hasil penelitiannya menemukan dua bentuk perilaku kepemimpinan yakni perilaku pemimpin yang berorientasi karyawan (employee centered behavior) yakni menekankan pada hubungan antar pribadi dan pemimpin yang berorientasi tugas (job centered behavior) menekankan pada aspek teknis dari tugas atau pekerjaan.

Sebagaimana dijelaskan Harsey dan Blancard (1994:178) bahwa Kepemimpinan situasioanal didasarkan atas hubungan antara kadar bimbingan dan arahan (perilaku tugas) yang diberikan pemimpin; kadar hubungan sosioemosional (perilaku hubungan) yang disediakan pemimpin; dan level kesiapan (kematangan) yang diperlihatkan pengikut dalam pelaksanaan tugas, fungsi atau tujuan tertentu. Kepemimpinan situasional membasiskan konsepsinya pada hal yang disebut sebagai maturity atau kematagan. Maturity ini didefinisikan sebagai kemampuan dan kemauan (ability and willingness) orang-orang untuk memikul tanggungjawab untuk mengarahkan perilaku mereka sendiri.

Kepemimpinan situasional pada dasarnya menjelaskan bahwa efektivitas kepemimpinan sangat tergantung pada situasi yang dihadapi, hal ini sekaligus berarti bahwa tidak ada satupun gaya kepemimpinan yang cocok untuk berbagai situasi yang berbeda. Untuk lebih jelasnya lihatlah gambar di bawah ini;

Gambar 1 Kepemimpinan Situasional

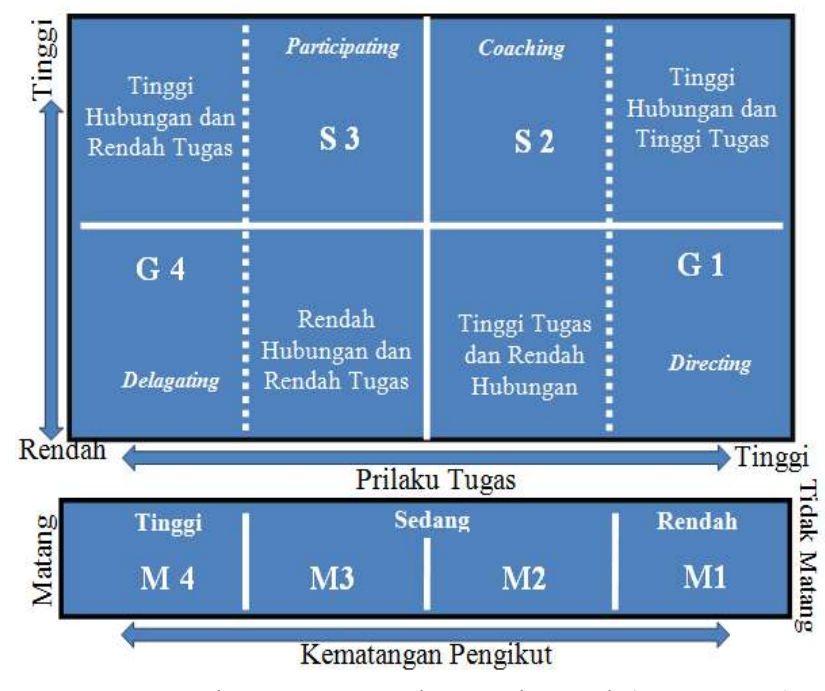

Sumber: Hersey dan Balncard (1994:178) 
Gambar 1 menggambarkan hubungan antara kematangan berkaitan dengan tugas dengan gaya kepemimpinan yang sesuai diterapkan pada saat pengikut bergerak dari keadaan tidak matang ke level yang lebih matang. Perilaku tugas adalah kadar sejauhmana pemimpin menyediakan arahan dengan memberitahukan kepada mereka apa yang harus dilakukan, kapan melakukan, di mana melakuknnya dan bagaimanya cara melakukannya.

Sedangkan perilaku hubungan adalah sejauhmana pemimpin melakukan hubungan dua arah dengan bawahanya yakni menyediakan dorongan psikologis dan memudahkan perilaku. Hal ini pemimpin secara aktif menyimak dan mundukung upaya karyawan dalam melaksakan pekerjaan mereka. Sedangkan kematangan pengikut adalah persoalan kadar. Gaya kepemimpinan yang sesuai bagi masing-masing level kematangan mencakup kombinasi perilaku tugas (directive) dan perilaku dukungan (supportive) yang tepat.

Memberitahukan adalah bagi tingkat kematangan yang rendah. Orang-orang yang tidak mampu dan tidak mau (M1) memikul tanggung jawab untuk melakukan sesuatu adalah tidak kompeten dan tidak yakin.Dalam banyak hal, ketidakmauan mereka adalah adalah ketidakyakinan dalam kaitannya dengan pelaksanaan tugas tertentu. Dengan demikian gaya memberitahukan yang direktif (G1) yang menyediakan arahan dan supervisi yang spesifik dan jelas memiliki kemungkinan efektif yang lebih tinggi dengan orang-orang yang berada pada level kematangan seperti itu. Gaya ini diacu sebagai memberitahukan karena dicirikan oleh perilaku pemimpin yang menetapkan peranan dan memberitahu orangorannya tentang apa, bagaimana, kapan dan dimana melakukan berbagai tugas. Dalam gaya ini tercakup perilaku tinggi tugas dan rendah hubungan.

Menjajakan adalah bagi tingkat kematangan rendah ke sedang. Orang-orang yang tidak mampu tetapi mau (M2) memikul tanggungjawab untuk melakukan sesuatu tugas adalah yakin akan tetapi kurang memiliki keterampilan pada saat sekarang. Dengan demikian gaya menjajakan (S2) yang menyediakan perilaku direktif, karena mereka kurang mampu tetapi juga perilaku suportif untuk memperkuat kemauan dan antusias mereka merupakan gaya yang paling sesuai dengan orang-orang yang berada pada level kematangan ini. Pemimpin masih meyediakan hampir seluruh arahan akan tetapi melalui komunikasi dua arah dan 
penjelasan, pemimpin berusaha agar secara psikologis pengikut turut andil dalam perilaku yang diinginkan. Dalam gaya ini tercakup perilaku yang tinggi tugas dan tinggi hubungan.

Mengikutsertakan adalah bagi tingkat kematangan sedang ke tinggi. Orangorang yang berada pada tingkat kematangan ini mampu tetapi tidak mau (M3) melakukan hal-hal yang diinginkan pemimpin. Ketidakmauan mereka seringkali karena kurang yakin atau tidak merasa aman.Tetapi apabila mereka kompeten namun tidak mau, keengganan mereka lebih merupakan masalah motivasi.Hal ini perlu membuka saluran komunikasi dua arah untuk mendukung upaya pengikut dalam menggunakan kemampuan yang telah mereka miliki. Dengan demikian gaya partisipatif yang suportif dan tidak direktif memiliki kemungkinan efektif paling tinggi dengan orang-orang pada tingkat kematangan ini. Gaya ini mencakup perilaku tinggi hubungan dan rendah tugas.

Mendelegasikan adalah bagi tingkat kematangan tinggi. Orang-orang dengan tingkat kematangan seperti ini adalah mampu dan mau atau yakin memikul tanggungjawab. Dengan gaya mendelagasikan yang berprofil rendah (G4) yang menyediakan arahan atau dukungan yang rendah memiliki kemungkinan efektif paling tinggi dengan orang-orang yang berada pada level ini. Meskipun pemimpin masih mengidentifikasi masalah, akan teapai tanggungjawab untuk melaksanakan rencana diberikan kepada pengikutnya. Dalam gaya ini tercakup perilaku yang rendah hubungan dan rendah tugas.

Hal diatas juga diperkuat oleh al-Ghazali dalam Ihya Ulumudin mencantumkan nama Khalil bin Ahmad yang berkata: "Orang itu ada empat macam:Pertama, Rojulun Yadri wa Yadri Annahu Yadri (Seseorang yang tahu, dan ia tahu kalau dirinya tahu). Ia adalah orang yang berilmu. Ikutilah ia. Kedua, Rojulun Yadri wa Laa Yadri Annahu Yadri (Seseorang yang tahu, tapi ia tidak tahu kalau dirinya tahu). Bangunkanlah ia. Ketiga, Rojulun Laa Yadri Annahu Laa Yadri (Seseorang yang tidak tahu, tapi ia tahu (sadar diri) kalau ia tidak tahu). Ia adalah orang yang minta petunjuk. Tunjukkanlah ia. Keempat, Rojulun Laa Yadri wa Laa Yadri Annahu Laa Yadri (Seseorang yang tidak tahu, dan ia tidak tahu kalau dirinya tidak tahu). Ia adalah orang bodoh, Tolaklah ia (Rusn, 1998:38-39).

Oleh karena itu seorang pemimpin memerlukan latihan untuk mengenali 
pengikutnya dalam menggunakan kepemimpinan situsaional. Blanchard (2007: 119) mengemukakan tiga keterampilan pemimpin situasional; mendiagnosis, fleksibel dan bermitra menuju kesuksesan. Pertama, mendiagnosis harus menentukan tingkat perkembangan pengikut. Kuncinya dalam hal ini ada dua faktor, yaitu kemampuan dan komitmen. Kedua, fleksibilitas menggunakan beragam gaya kepemimpinan. Ketiga, bermitra untuk sukses memberikan petunjuk bagaimana menciptakan hubungan kepemimpinan yang saling melengkapi. Sehingga memberikan kesempatan kepada orang-orang untuk meminta gaya kepemimpinan yang mereka butuhkan dari manajer.

\section{Metode Penelitian}

Penelitian ini mengungkap makna di balik aktivitas kepemimpinan Kiai dalam pengembangan pendidikan formal pesantren Full day Sunan Ampel Banyuwangi. Sebagai sebuah tindakan social (social action) yang dikonstruksi oleh aktor (Kiai), kepemimpinan memiliki gaya atau tipikal yang memiliki kecederungan berubah-ubah. Apa yang ditampilkan oleh Kiai secara simbolik dan verbalistik dalam merupakan persoalan utama yang akan dicari oleh penelitian ini. Sejalan dengan itu, penelitian ini cenderung memilih metode kualitatif dengan jenis pendekatannya yang bercorak fenomenologis. Pendekatan ini, sangat relevan dalam upaya menggali pemaknaan atas kepemimpinan Kiai dalam mengembangkan pendidikan formal pesantren. Berdasarkan pendekatan ini, maka pemaknaan yang dicari oleh peneliti bukanlah makna individual, melainkan makna universal yang disistematisasikan berdasarkan makna-makna yang berasal dari individu-individu yang menjadi dan berkaitan subjek penelitian ini (Creswell, 2004:10)

Untuk mempermudah dalam mendapatkan informasi atau data-data dalam penelitian, maka peneliti menetapkan siapasaja yang menjadi subjek penelitian/informan.Teknik dalam Penentuan subyek penelitian/informan dalam penelitian ini menggunakan teknik purposive. Menurut Creswell (2015:407) dalam teknik tersebut, peneliti secara sengaja memilih individu dan tempat untuk mempelajari atau memahami fenomena sentral. Oleh karena itu peneliti sudah menentukan siapasaja yang menjadi informan. Informan tersebut di antaranya 
Kiai, ustad/ustadah, menantu Kiai, pengurus pesantren, santriwan dan santriwati, tokoh masyarakat dan yang tidak kalah pentingnya adalah alumni dari pesantren tersebut.

Dalam penumpulan data terdapat teknik untuk mendapatkan informasi yang berkenaan dengan fokus dan tujuan penelitian menurut Creswell (2015:420) yaitu observasi, wawancara, dokumen dan bahan audiovisual. Untukmemperoleh data secara holistik dan integratif serta mempertimbangkan dengan fokus dan tujuan penelitian maka pengumpulan data dalam penelitian ini memakai teknik yang ditawarkan oleh Creswell. Adapun proses analisisnya dilakukan dengan beberapa tahap yang disebut oleh Mills dan Huberman (2014:429) ada tiga tahap yakni tiga tahap; data condensation, data display dan conclusion drawing/verifiyin. Sedangkan keabsahan data dalam penelitian ini yaitu menggunakan trianggulasi, yang sesungguhnya bisa dilakukandengan teknik sumber, metode, investigasi dan teori yang berbeda-beda. Metode ini diambil tringulasi dalam penelitian ini dilakukan dengan cara menggunakan pengumpulan data tentang kepemimpinan Kiai yang berbeda-beda dariuntukmendapatkan data darisumber informan yang sama (Sugiyono, 2016:330).

\section{Hasil}

\section{Diagnosis Kiai}

Proses identifikasi bawahan yang dilakukan oleh KH. Miftahuddin Yahya (sering dipanggil dengan sebutan Kiai Miftah), pengasuh pesantren Full Day Sunan Ampel Banyuwangi terlihat juga dilakukan dengan mempertimbangkan kebutuhan pekerjaan dalam hubungannya dengan sumber daya yang dimilikinya. Pendidirian pendidikan formal di pesantrennya merupakan permintaan masyarakat.

Awalnya Kiai tidak berencana untuk mengembangkan pendidikan formal. Artinya, tujuan dipusatkan pada pengembangan dan penyebaran nilai dan ajaran agama sebagaimana orientasi pendidikan pada pesantren salaf pada umumnya. Namun, beberapa jamaah Kiai kemudian memberikan masukan padanya, untuk mengembangkan pendidikan formal di pesantren. Pada situasi demikian Kiai tentu belum sepenuhnya memiliki kesiapan untuk memenuhi harapan masyarakat 
tersebut.

Titik ketidaksiapannya tentu adalah pada aspek ketersediaan bawahanya yang dipandang ahli dalam mendirikan dan mengembangkan pendidikan formal. Beberapa santri Kiai dan pengurus pesantren kala itu, memang sangat tabu dalam usaha pengembangan pendidikan formal. Menghadapi masalah yang demikian, Kiai Miftah kemudian berkonsultasi dengan pesantren tempatnya belajar dulu, yakni pesantren Al Islam. Pada akhirnya, ia mendapatkan solusi untuk menangani masalah ketidaksiapan SDM pesantren dalam mengembangkan pendidikan formalnya. Dalam ceritanya, pihak pesantren Al Islam akan mengirim beberapa santri untuk membantu mendirikan dan mengembangkan pendidikan formal di pesantrennya.

Salah satu santri yang ditugaskan mengembangkan pendidikan formal di pesantren ini adalah Usman Wahyudi. Menurut pemaparanya, kedatangannya ke pesantren Sunan Ampel Banyuwangi adalah diamanahkan untuk mengembangkan pendidikan formal sebagaimana di pesantren Al Islam. Lengkapnya, beliau menuturkan,

"Saya datang ke pesantren ini sebagai guru tugas. Saat tiba di sini. Kami langsung menghadap ke Kiai Miftah. Kiai mengajak kemudian menyampakan bahwa pengembangan pendidikan formal di pesantren ini dipasrahkan ke saya dan teman santri tugasan lain. Santri itu santri tugas berjumlah tiga orang, saya sama dua teman lainnya. Kami bertiga memang ditugaskan oleh pesantren Al Islam untuk mengembangkan pendidikan pesantren. Sampai di sini ya kamu laksanakan tugas tersebut. Sebanarnya kami juga tidak begitu mengerti persolan pengembangan pendidikan formal pesantren. Namun karena sudah tanggung jawab yang kami lakukan semampunya. Awal yang kami lakukan adalah menyusun kurikulum yang bermutu, tentunya sesuai dengan apa yang ada di pesantren kami dulu. Setelah itu baru kemudia perbaikan operasional dan struktur pendidikannya".

\section{Pengarahan dan Bimbingan Kepada Civitas Pesantren dalam Pengembangan Pendidikan Formal}

Berdasarkan observasi yang dilakukan, ada dua elemen operasional pengarahan dan bimbingan yang masing berbeda. Keduanya adalah arahan dan bimbingan pengembagan pendidikan formal dan arahan dan bimbingan dalam pengembangan pendidikan lokal pesantren. Arahan dan bimbingan pendidikan formal dilaksanakan guna peningkatan mutu kualitas penyelenggaran pendidikan 
formal. Sedangkan arahan dan bimbingan pendidikan lokal pesantren berkaitan dengan pengembangan tradisi klasikal pendidikan pesantren.

Kedua arahan ini mengindikasikan adanya dua proses arahan dan bimbingan yang berbeda. Hal tersebut sebagaimana yang diungkapkan oleh Umi Kholifah,

"sejak awal begini, proses arahan dan bimbingan untuk lembaga formal, Kiai sejak awal percaya pada guru tugas dari Al Islam. Tentu arahan dan bimbingan yang diterima oleh meraka kebanyakan dari guru-guru pesantrennya. Sedangkan untuk masalah pendidikan yang sejak awal Kiai rintis itu yang dilakukan oleh Kiai sendiri. Biasanya di dalamnya juga melibatkan santri-santri senior seperti Supriyono dan Imam Ghazali. Artinya apa? arahan kyainya dalam pengembangan pendidikan formal itu menyangkut tentang bagaimana pengembangan pendidikan formal di pesantren ini tidak bersinergi dengan pengembangan pendidikan pesantren yang digagasnya dari dulu-dulu. Dalam bahasa lain pak, Kiai dalam pengarahan dan bimbingannya itu condong pada penguatan pendidikan pesantren sacara keseluruhan. Itu yang dilakukan sejak awal".

\section{Pelimpahan Wewenang Kepada Civitas Pesantren dalam Pengembangan Pendidikan Formal}

Kiai Miftah dalam melakukan proses penyampaian informasi tugas pada bawahanya, nampak mempertimbangkan kualitas bawahannya. Dalam hal ini yang menutrukan,

"kalau wawasan, tidak diragukan lagi pak, saya juga santri Al Islam kan, saya paham pemahaman dan pengetahuan santri di pesantren itu. Hanya saja, saya berasumsi begini pak, santri tugas yang ditugaskan pesantren Al Islam itu sudah memiliki wawasan dalam pengembangan pendidikan formal. Sebab mereka sudah diberikan bekal tentunya. Namun yang menurut saya yang kurang dari meraka itu, bagaiamana mereka bekerja di pesantren ini.Saya jujur pesantren ini tentu berbeda dengan pesantren Al Islam, pesantren saya dulu. Sebab pesantren ini ingin memadukan karekter salaf sebagaimana pesantren Blok Agung dan juga mengembangkan pendidikan formal sebagaiamana pesantren Al Islam. Itu yang berbeda. Ingin modern, namun menghilangkan orientasi kesalafannya pak. Karana orientasi ini pak. Saya pastinya harus juga terlibat pada penyusuan inovasi pendidikan formal bersama pada "civitas pesantren", semuanya. Tidak melepas secara total. Saya pasti dan wajib membimbing mereka agar sesuai dengan tujuan utama yang saya harap-harapkan ini. Makanya di awal dulu, dibeberapa kesempatan saya selalu menyampaikan dan memberikan contoh. Dulu sering saya membuat jadwal pengajian bareng dengan mereka. Disana saya meberikan contoh bahwa dalam penyusunan rencana harus mempertimbangkan dua aspek penting yang ingin dikembangkan di 
pesantren yakni orientasi pengembangan mutu pendidikan formal dan upaya pengembangan pendidikan pesantren".

Beliau menambahkan

"dalam kitab ihya' ulumuddin. Dijelaskan begini, ada empat orang yang dapat dijadikan teman yang baik dalam menjalani hidup. Njenengan kan isnyalah paham itu. Ada orang yang pahamnya baik, namun tidak tahu kalau pemahamannya itu beguna. Dia tidak paham dan memiliki kapasitas dalam melakukan sesuatu dengan ilmunya. Mereka (para santri tugas) dalam tahap pendirian awal tidak demikian. Mereka paham ilmunya penting untuk dijadikan alat pengembangan pendidikan pesantren ini. Ada juga orang yang paham, dan dia mengerti tidak paham kalau dia paham. Ini yang mirip dengan kondisi struktural pendidikan kami itu. Mereka paham kalau dalam mengembangkan pendidikan, harus memahami apa yang tujuan pesantren ini sejak awal. Dengan demikian, tidak heran kan ketika saya memberikan dampingan pada tahap pendirian secara intens. Sebenarnya ada empat kan pak, yang disebutkan al Ghazali itu. Dari keempatnya, ya tadi itu yang cocok menggambarkan para pengembang awal pedidikan formal pesantren ini”.

Berdasarkan hal ini hal yang jadi pertimbangan dalam menentukan strategi penggambaran dan pelimpihan tugas pada bawahannya Kiai Miftah didasarkan pada hasil identifikasi kualitas bawahannya. Pada tahap awal pendirian, titik yang dirasa masih lemah dari komponen struktur bawahannya adalah pada aspek pemahaman pengembangan integratif pesantren salah dengan inovasi pendidikan formalnya. Dalam hemat peneliti, tentu yang dimaksud adalah wawasan manajerial pengembangan pendidikan yang memadukan orientasi pesanatren salaf dengan pendidikan formal modern. Artinya, dalam pandangan Kiai beberapa guru tugas masih memiliki kelemahan dalam aspek kualitas wawasannya. Adapun integritasnya tentu sudah tidak diragukan.

\section{E. Pembahasan}

\section{Diagnosis Kiai}

Ada tawaran konsepsional yang tentu merupakan bagian dari kontruksi SLT. Blanchard dan Hersey megatakan situasi lingkungan merupakan hal yang tidak dapat dipisahkan dari gaya tindakan kepemimpinan seseorang. Menurutnya, setidaknya tidak dapat dilepaskan dari dua yakni gaya dan harapan seluruh komponen organisiasi. Keduanya harus dipertimbangan secara matang dalam 
substansial relasi komponen organisasi yang terdapat dalam internal maupun ekternal organisasi. Untuk lebih jelasnya sebagaimana gambar berikut ini

\section{Gambar 2 Ruang Lingkup Diagnostic Framework Situasi dan Kesiapan Civitas}

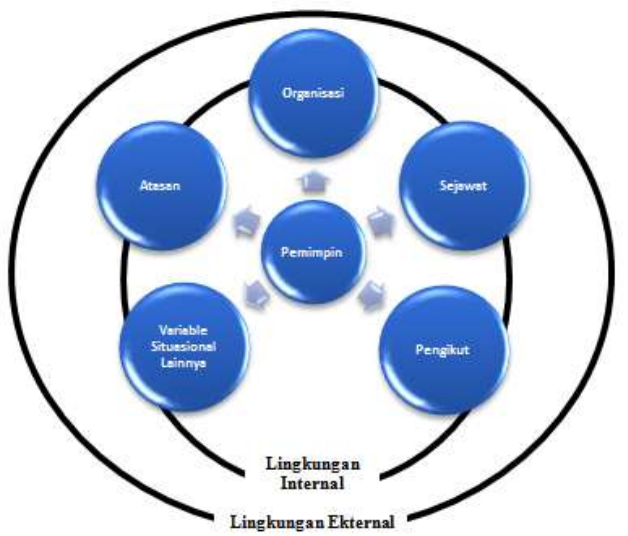

Sumber: Blanchard dan Hersey (1994:150)

Berdasarkan komposisi yang disusun di atas, dalam mendiagnosis adalah mempertimbangkan beberapa komponen yang saling berpengaruh dalam menciptakan roda orientas kerja organisasi. Tentu komponen yang dimaksud, baik yang berasal dan lingkungan internal maupun eksternal. Komponen internal meliputi struktural organisasi dan seluruh variabel yang berhubungan secara langsung dalam ruang intern organsasi. Sedangkan komponen ekternal adalah semua hal berada dalam jalur relasi ekstern struktural organisasi.

Adapun proses identifikasi yang dilakukan Kiai guna mempersiapkan pengembangan pendidikan formal adalah juga menganalisa kesiapan dan situasi internal dan juga eksternal. Pihak internal merupakan internal kepengurusan pesantren yang sejak lama bergabung dan ikut mengembangkan pendidikan pesantren. Pada pesantren Full Day Sunan Ampel Banyuwangi, seperti santrisantri senior dan internal kepengurusan yayasan.

Sedangkan diangnosa ekternal, merupakan semua variabel potensial di luar pesantren yang yang dapat dijadikan bagian dari civitas atau tanaga pengembangan pendidikan formal. Hal demikian ini sebagaimana yang dilakukan Kiai Miftah dalam mengembangkan pendidikan pendidikan formal pesantren Full Day Sunan Ampel Banyuwangi. Telah dijelaskan di awal bahwa Kiai Miftah merasa tidak cukup dengan melakukan pembacaan pada kesiapan-kesiapan atau 
situasi lingkungan internal pesantren. Sebagai pesantren salaf tentu untuk mengembangan pendidikan formal perlu tenaga baru yang dapat berinovasi. Mau tidak mau, ia memerlukan civitas profesional yang minimal memiliki pengalam dalam pengembangan pendidikan formal. Akhirnya, Kiai Miftah melakukan diagnosis pada potensi pihak yang membantu menyiapkan kematangan civitas pesantren. Salah satu pihak yang dapat mendukung adalah pesantren Al Islam Ponorogo.

\section{Perilaku Kiai Memberikan Pengarahan dan Bimbingan Kepada Civitas} Pesantren dalam Pengembangan Pendidikan Formal

Pasca diagnosis civitas pesantren, hal yang perlu dilakukan oleh seorang pemimpin adalah melakukan cross check situasi kematangan yang diperlukan apakah sudah memenuhi atau tidak. Adalah hal yang mahal, jika kematangan civitas pesantren berada pada kondisi kematangan yang maksimal. Apalagi pesantren sebagai lembaga tradisional, pendirian pendidikan formal terbilang merupakan upaya pengembangan pesantren yang sebelumnya tidak pernah dilakukan. Pendidikan formal merupakan upaya baru pesantren dalam menjawab tetangan zaman.

Blanchard membangun sebuah anggapan bahwa arahan dan bimbingan dapat disesuikan dangan pengharkatan kematangan kompetensi dan komitmen bawahan sebagaimana yang dikemukan di awal. Dalam pengharkatannya ia menjelaskan ada empat kategori bawah yakni M1, M2, M3 dan M4. Adapun konstruksi yang dibangun sebagaimana tergambar di bawah ini.

\section{Gambar 3 Kontruksi Arahan dan Bimbingan Kepemimpinan Situasional}

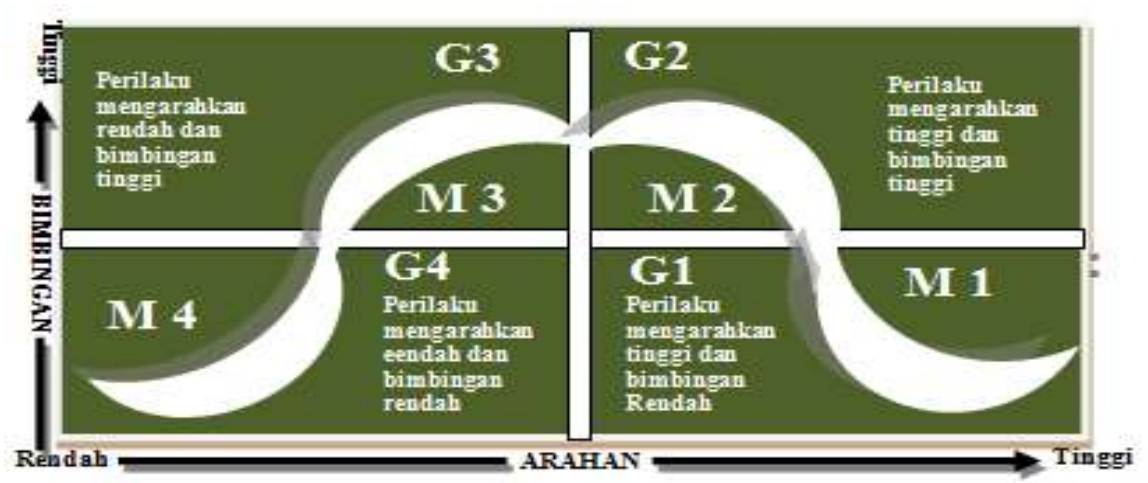

Sumber: Blanchard (2007:131) 
M1 adalah situasi kondisi hasil diagnosis bawahan dengan kompetensi dan komitmen lemah. Pada kondisi ini-dalam pandangannya-proses arahan tinggi dan bimbingan dapat direndahkan (G1). M2 adalah kondisi low some competence and commitment. Pada kondisi ini, arahan dan bimbingan sama-sama tinggi (G2). M3 adalah kondisi moderate some competence and commitment. Pada jenis bawahan dengan kematangan tersebut proses arahan rendah dan bimbingan tinggi (G3). Terakhir, M4 adalah bawahan dengan highcompetence and commitment. Kodisi terakhir ini arahan dan bimbingan dapat rendah secara bersama-sama (G4).

Tidak heran, jika pada situasi ini Kiai lebih "cerewet" atau banyak bicara tentang pelaksanaan tugas pengembangan pendidikan formalnya. Sebagimana diakui beberapa santri senior di pesantren Full Day Sunan Ampel Banyuwangi. Sedangkan pada situasi rate M3. Kiai lebih nampak melakukan bimbingannya yang sifatnya pengembangan peningkatan motifasi kerja. Pada situasi ini, Kiai kadang terlibat pada kerja-kerja organisasi untuk memberikan bimbingan secara langsung pada bawahan (guiding). Tidak diherankan jika pada tahap pendirian, prosesnya dilakukan secara lebih inten hingga baik melalui komunikasi formal, lebih-lebih nonformal.

Adapun pada masa pengembangan, beberapa bawahan telah mengalami kondisi kematang yang sempurna. Beberapa bagian civitas pesantren-kompetensi dan komitmennya, ada yang berada pada rate M4. Kiai pun akhirnya, memperlemah arahan dan bimbingan dilakukan pada mereka. Mereka dianggap telah bisa bekerja secara kreatif dan mampu mengembangkan pendidikan formal pesantren. Civitas yang berada pada kondisi kematangan tersebut, serta merta berposisi sebagai penanggung jawab kerja civitas lain yang belum mencapai kematangan yang diharapkan, M4. Dengan kata lain, Kiai pun dalam arahan dan bimbinganya pada tahap pengembangan pendidikan formal, dibantu oleh civitas pesantren yang berada pada tingkat kematangan M4.

\section{Perilaku Kiai Memberikan Pelimpahan Wewenang Kepada Civitas Pesantren dalam Pengembangan Pendidikan Formal}

Untuk membahas terkait dengan perilaku Kiai dalam pemberian dukungan dan wewenang, tentu tidak lepas dari diskursus ada pada kajian kepemimpinan sebelumnya. Salah satu yang intens menjadi perbincangan penting dalam 
kontruksi konsepsional perilaku kepemimpinan adalah hal yang berkaitan dengan pelimpahan wewenang dan sesuatu yang menyertainya. Setiap proses pelimpahan wewenang selalu dikaitkan dengan pemberian dukungan kuasa kerja, hal demikian yeng kemudian dapat dihubungkan penjelasannya dengan instrumen LBDQ. Dalam penjelasan yang digagas oleh peneliti Univrsiats Ohio ini merupakan konsepsi yang mempertemukan pelimpahan task dalam inter relasi pemimpin dan bawahanya.

Untuk melihat konsepsi teoretik dalam penelitian ini, peneliti tertarik untuk menggambarkan terlebih dahulu beberapa kerangka teoriti yang penting untuk dibahas. Untuk jelasnya, lihat gambar berikut ini:

\section{Gambar 4 Konsepsi Relasi Gaya Kepemimpinan dan Maturity Rate Dalam Berbagai Perspektif}

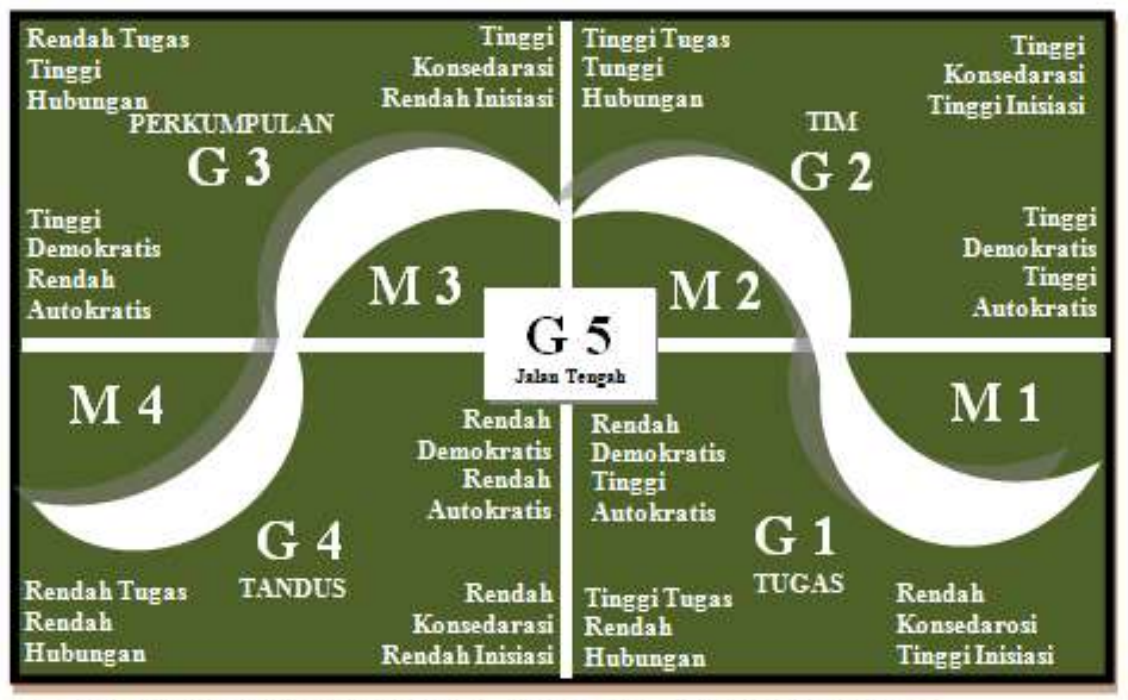

Disusun Peneliti Berdasar Pada Ragam Teori Kepemimpinan Situasional

Hal demikian yang nampak dilakukan oleh Kiai dalam mengembangkan pendidikan formal di pesantren Full Day Sunam Ampel Banyuwangi pada awal pendidirian pendidikan formal pesantrennya, seluruh civitas berada pada kondisi M3. Pada kondisi ini, inisiatif sangat tinggi. Artinya, pelimpahan kerja dilakukan dengan arahan struktural. Dengan demikian, maka sebaliknya konsidarasi sangat minim sekali. Seluruh civitas pesantren bekerja atas perintah yang rinci dari Kiai. Pelimpahan kerja dengan model ini nampak autokratis. Namun, anehnya hubungan Kiai pada situasi tahap pendirian ini, diakui civitasnya lebih intens dibanding pada masa pengembangan saat ini. 
Pada masa pendirian, ada dua varian bentuk kondisi kematangan yang berbeda. Civitas yang berasal dari santri senior internal disebutkan memimiliki kematangan kompetensi yang lemah, sedangkan komitmennya tinggi. Adapun civitas yang berasal dari santi tugas pesantren Al Islam Ponorogo, diyakini oleh Kiai kelompok bawahan yang memiliki kompetensi tinggi, sedangkan komitmennya masih diragukan, atau lemah. Pada kondisi dua kematangan ini Kiai tentu mempraktikkan dua gaya sekaligus. Pada santri seniornya, ia terlihat lebih meningkatkan iniasiasi struktural dan pada santri tugas pesantren Al Islam Ponorogo dilakukan dengan meningkatkan sisi konsiderasinya.

Fakta di atas juga dapat dikaji bahwa Kiai dalam pelimpahan kerja pada bawahanya tidak didasarkan pada keinginan mereka untuk bekerja. Namun disesuaikan dengan komitmen, kompetensi dan kompatibilitas kesadaran agama. Artinya, Kiai sebenarnya telah mengajarakan konsep pendelegasian kerja profetik atau seperti nabi Muhammad SAW. Hal ini sebagaimana yang digambarkan dalam Hadist Nabi berikut:

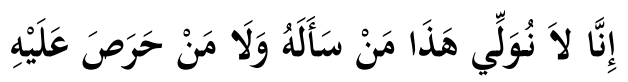

Artinya: "Kami tidak menyerahkan kepemimpinan ini kepada orang yang memintanya dan tidak pula kepada orang yang berambisi untuk mendapatkannya."(HR. al-Bukhari no. 7149 dan Muslim no. 1733)

\section{F. Kesimpulan}

Pengenalan situasi dan kesiapan guna mendirikan pendidikan formal dilakukan oleh Kiai secara mandiri pada dua lingkungan internal dan eksternal. Ruang lingkup internalnya terdiri dari meliputi internal pengurus yayasan, keluarga Kiai dan santri senior. Sedangkan, ekternal terdiri institusi atau perorangan yang secara profesional terbukti mampu mengembangkan pendidikan formal. Proses ini dilakukan untuk membaca dan mempersipakan civitas pengembangan pendidikan formal pesantren.

Arahan dan bimbingan Kiai berdasarkan pada tingkatan kematangan. Pada tahap pendirian awal lembaga formalnya, berada pada midle arearate dengan klasifikasi dua bagian yakni civitas dengan tinggi kompetensi dan lemah komitmen dan lemah kompetensi dan tinggi komitmennya. Pada kondisi yang 
pertama, arahan Kiai lebih tinggi dari pada bimbingannya. Sedangkan situasi kedua, bimbinggnya lebih tinggi dari pada arahannya. Dengan demikian intensitas dan kualitas arahan Kiai bergerak berbanding terbalik dengan tingkat kematangan komptensi civitas pesantren. Sedangkan bimbingannya berbanding terbalik dengan kondisi kematangan komitmennya. Adapun berkaitan dengan pola komunikasinya, ada perubahan channel yang dipilih. Pemilihan saluran komunikasi dilakukan berbeda dengan melihat tingkat kompetensi kematangan civitas pesantren juga. Pada civitas pesantren dengan kategori middle area, komunikasi lebih banyak dilakukan melalui jalur non formal. Namun pada kondisi bawahan kematangan sempurna, komunikasi lebih banyak dilakukan dalam acaraacara formal.

Proses pendelegasian yang demikian untuk mencapai model ideal atau efektif dalam pendelagasian wewenangan, yakni model G4 "kosedaratif delagatif". Prosesnya dilakukan dengan membuka kesempatan pertimbangan secara luas dan memerintahkan kerja dengan basis keperacayaan.

\section{Daftar Pustaka}

Amrullah, Abdul Malik Karim. 2011. Perubahan Model Penyelenggaraan Pendidikan Pesantren, Disertasi Malang, Universitas Negeri Malang.

Blanchard, Ken. 2007. Leading At A Higher Level, Alih bahasa: Ponijan Liaw dan Hendra Lim, Jakarta: PT Alex Media Komputindo

Certo. C, Certo .T. 2009. Modern Management: Concept and Skills, Eleventh Edition.

Charles, L., and Steven L. McShane, 2008. Principles of Management. New York: McGraw-Hill Irwin.

Creswell, John. 2015. Riset Pendidikan: Perencanaan, Pelaksanaan, dan Evaluasi Riset Kualitatif \& Kuantitatif, Alih Bahasa Helly Prajitno \& Sri Mulyantini Soetjipto. Yogyakarta: Pustaka Pelajar.

E. Mulyasa. 2004. Manajemen Berbasis Sekolah. Bandang: Rosda Karya.

Gini, Al \& Ronald M. Green, 2013.10 Virtues of Outstanding Leaders (Chicester: John Wiley \& Sons Ltd.

Hasan, Tholchah. 1987. Islam dalam Perspektif Sosial Budaya. Jakarta: Galara Nusantara.

Hersey, Paul dan Kenneth H. Blanchard. 1994. Manajemen Perilaku Organisasi: Pendayagunaan Sumber Daya Manusia. Penerjemah: Agus Dharma. Jakarta: Erlangga.

Hubberman, A. Michael \& Matthew B. Miles. 1994. Data Manajement and Analysis Methods, dalam Norman K. Denzim \& Yvona S. Lincoln (Edit.), Handbook of Qualitative and Quantitative Research.London: Sage Publication. 
Ivancevich Gibson, Donnely Jr.. 2007. Organisasi (Perilaku, Struktur, Proses), Jilid I Edisi Lima.Jakarta: Erlangga.

Jawa Pos, Indonesia berlakukan MEA, Edisi 15 Desember 2015. Di Indonesia, MEA resmi diberlakukan oleh Presiden Joko Widodo pada tahun 2015.

Mardiyah. 2012. Kepemimpinan Kiai dalam Memelihara Budaya Organisasi, Malang, Aditya Media Publishing.

Rusn, Abidin Ibnu,.1998. Pemikiran Al-Ghazali Tentang Pendidikan. Yogyakarta: Pustaka Pelajar.

Shodiq, Muhammad. 2011. Kepemimpinan Kiai Nasib dalam Meningkatkan Mutu Pesantren, Studi pada Pesantren Al-Hikam Malang, Pesantren Luhur AlHusna Surabaya, dan Pesantren Mahasiswa An-Nur Surabaya. DisertasiUniversitas Negeri Malang.

Stephen Robbins dan Judge, Timothy. 2015. Perilaku Organisasi (Organizasional Behavior). Jakarta: Salemba Empat.

Sugiyono. 2016. Metode Penelitian Pendidikan (Pendekatan kuantitatif, kualitatif, dan $R \& D$ ). Bandung: ALFABETA

Suhartini, A.Halim, Rr., M. ChoirulArif, \& A. Sunarto. 2005. Manajemen Pesantren. Sewon: Pustaka Pesantren. 